\title{
IDENTIFIKASI LANGGAM GAYA ARSITEKTUR TRANSISI/PERALIHAN SERTA KARAKTER VISUAL FASAD PADA ARSITEKTUR PENINGGALAN KOLONIAL DI KECAMATAN BANDA SAKTI KOTA LHOKSEUMAWE
}

\author{
Armelia Dafrina $^{1^{*}}$, Soraya Masthura Hassan ${ }^{2}$, Aulia zahara ${ }^{3}$ \\ 1*Program Studi Arsitektur Universitas Malikussaleh, email: armelia@unimal.ac.id \\ 2Program Studi Artsitektur Universitas Malikussaeh, email: soraya.masthura@unimal.ac.id \\ ${ }^{3}$ Jurusan Arsitektur Universitas Syiah Kuala, email: aulia.zahra1477@ gmail.com
}

\begin{abstract}
ABSTRAK
Kota Lhokseumawe merupakan kota yang menyimpan berbagai peninggalan-peninggalan bersejarah, tetapi hanya sebagian kecil yang dapat perhatian khusus baik dari Pemerintah Kota Lhokseumawe maupun masyarakat setempat yang berada disekitar kawasan peninggalan Arsitektur Kolonial Belanda. Salah satu peninggalan yang ada di kota ini yaitu peninggalan Kolonial Belanda berupa Hunian/Rumah tinggal, Gedung Pendididkan, Gedung Perkantoran maupun berupa Kompleks Perkuburan. Keberadaan bangunan ini salah satu konsep Arsitektur perencanaan kota Kolonial yang di bangun oleh Hindia Belanda yakni perpaduan model bangunan Belanda dengan teknologi bangunan daerah tropis. Model bangunan berarsitektur Kolonial ini mempunyai kekhasan bentuk bangunan terutama pada fasade bangunannya. Peninggalan bangunan Kolonial ini berubah Gaya dan Karakter Visualnya dari masa ke masa. Penelitian tentang Arsitektur Kolonial Transisi/Peralihan ini bertujuan untuk mendeskripsikan objek/bangunan pada kawasan Banda Sakti Kota Lhokseumawe dan mengidentifikasi Gaya Arsitektur Transisi/Peralihan serta karakter visual bangunan pada 3 bangunan bersejarah yang diteliti. Penelitian ini menggunakan metode analisis Kualitatif dengan melakukan pendekatan metode deskriptif analisis atau pemaparan kondisi. Metode analisis kualitatif dilakukan dengan observasi lapangan. Metode deskriptif analisis dilakukan dengan pendekatan historis. Dari hasil analisis penelitian ini diperoleh bahwa gaya dan karakter bangunan pos polisi, rumah dokter hewan Belanda dan rumah bangsawan Belanda teridentifikasi gaya arsitektur peninggalan Kolonial Belanda pada masa Transisi/peralihan (1890-1915).
\end{abstract}

Kata kunci: Pos Polisi,Rumah Dokter Hewan,Rumah bangsawan Belanda, Gaya/Style Bangunan, Karakter Visual, Kawasan Banda Sakti Lhokseumawe

Info Artikel:

Dikirim: 5 Agustus 2021; Revisi: 18 Agustus 2021; Diterima: 26 September 2021; Diterbitkan: 30 September 2021

(C)2021 The Author(s). Published by Arsitekno, Architecture Program, Universitas Malikussaleh, Aceh, Indonesia under the Creative Commons Attribution 4.0 International License (https://creativecommons.org/licenses/by/4.0/).

\section{PENDAHULUAN}

Seiring dengan perkembangan zaman, sebuah kota akan mengalami perubahan maupun pertumbuhan yang semakin maju. Tetapi hal itu tidak lepas dari sejarah atau cerita adanya kota tersebut. Dalam sebuah kota terdapat rangkaian sebuah sejarah yang bisa dilihat dari peninggalan atau warisan kekayaan arsitektur suatu bangunan bersejarh yang terdapat dikota itu. Indonesia negara yang memiliki beribu-ribu pulau tentu mempunyai banyak keanekaragaman benda berbentuk sejarah yang bisa mendeskripsikan karakter budaya yang khas pasa setiap kota. Kota Lhokseumawe merupakan salah satu kota sejarah yang sudah memainkan perannya sejak kemunculan Kerajaan Samudera Pasai sekitar abad ke-13. Kota Lhokseumawe semakin memainkan peran pentingnya ketika menjadi bagian dari kedaulatan Kesultanan Aceh sejak 
tahun 1524, masa kolonial dan perang kemerdekaan.Lhokseumawe tempo dulu menjadi salah satu tempat yang menjadi basis bagi kolonial. Baik yang berasal dari Belanda maupun Jepang. Hal ini ditandai dengan adanya perkuburan Belanda yang berada di Hagu Barat Laut, yang sekarang diatas kuburan tersebut telah dibangun sekolah SMK Negeri. Kereta api Aceh juga termasuk stasiun pasai Gambe yang dibangun pada saat pemerintahan Hindia Belanda pada tahun 1900-an. Beberapa tempat lainnnya juga ada peninggalan-peninggalan seperti di Benteng buatan Jepang yang terdapat di Cot Panggoi yang sekarang telah dijadikan tempat wisata Aceh yaitu dinamakan dengan Bukit Goa Jepang. Bangunan sejarah lain yaitu dapat ditemukan diseputaran kota lhokseumawe, seperti bangunan lama bekas perkantoran zaman dulu yang kini telah berubah menjadi bangunan toko.

Kantor Pos Polisi bangunan ini dulunya merupakan KantorPNKA dari tahun 1850-1951 dan sekarang baru berubah menjadi Pos polisi dari tahun 1951-sekarang. Fasade bangunan bergaya arsitektur Kolonialnya. Bangunan ini dibangun sekitar tahun 1850-an dan luas bangunan kurang lebih $84 \mathrm{~m}^{2}$. Bangunan ini sudah mengalami beberapa perubahan renovasi. Rumah Dokter hewan Belanda yang terletak di jalan Sultan Nahrisyah Lancang Garam ini sudah ada sejak tahun 1850-an yang merupakan bangunan peninggalan Belanda dan sudah beberapa kali direnovasi dari masa ke masa. Fungsi dari bangunan ini berubah seiring dengan pergantian kepemilikan rumah. Fungsi rumah dari masa ke masa tahun sebelum 60-an awalnya kepemilikan rumah ini merupakan Rumah Dinas Manteri Hewan Belanda, dan difungsikan sebagai rumah tinggalnya sekitar tahun 1960-1963. Dan sekarang dijadikan rumah tinggal. Bentuk belakang rumah ini sudah mengalami kerusakan. Hanya bagian depan yang terawat.Bangunan rumah bangsawan Belanda yang terletak di jalan Iskandar Muda ini adalah peninggalan Kolonial Belanda dan sangat berbeda dengan bangunan-bangunan yang ada disekitarnya. Dari hasil wawancara dapat diketahui bahwa bangunan ini sudah mengalami perumahan yaitu pada pondasi. Dimana pondasi yang dulu terbuat dari material kayu yang dulu sudah tidak layak pakai, dan kemudia digantidengan yang baru yang lebih kokoh. Rumah ini terdapat 4 kamar, ruang tamu, ruang keluarga, dapur dan kamar mandi.Gaya bangunan rumah ini adalah gaya Arsitektur Transisi/Peralihan dari Masa Kolonial Belanda. Rumah dengan Gaya Kolonial ini menjadi simbol untuk menentukan kelas atau status sosial seseorang. Arsitektur Kolonial ini juga memiliki aspek pembeda yang lain yaitu memiliki ciri khas pada desain ruang ruangnya, bentu dan struktur maupun material. Ruang bangunan utama menghadap ke halaman yang luas. Atap mirip dengan atap pelana dan limas an. Bahan material utama yaitu kayu, batu seng dan besi.Adapun tujuan penelitian dalam artikel ini yaitu untuk dapat mengetahui dan mengidentifikasi Gaya Arsitektur peninggalan Kolonial pada Masa Transisi/Peralihan serta cirri-ciri visual Arsitektur Peninggalan Kolonial di Kecamatan Banda Sakti Kota Lhokseumawe.

\section{METODE PENELITIAN}

Adapun macam penelitian yang akan diajukan adalah Analisis Kualititaf dengan melakukan pendekatan metode deskriptif analsisis atau pemaparan kondisi. Metode analisis kualitatif dilakukan dengan observasi lapangan. Metode deskriptif analisis dilakukan dengan pendekatan historis. Menurut Muhadjir [1], Adapun metode deskriptif yang dilakukan dengan langkah serta mengkoleksi data yang didapat dari hasil pengamatan di lapangan atau di Kecamatan Banda Sakti Kota Lhokseumawe, dokumentasi dan studi referensi serta literatur yang berkaitan dengan objek studi.Langkah awal penelitian yaitu melakukan observasi lapangan atau kegiatan survei pada objek peneltian dan pengunpulan data sekunder mengenai objek penelitian. Hasil daro observasi digunakan untuk mendapatkan gambaran fasade objek penelitian.

Setelah mengetahui gambaran dan fasade bangunan yang diteliti maka kemudian mendeskripsikan tiap elemen penyusun fasade atau visual dan gaya bangunan.setelah mendeskripsikan elemen-elemen penyusun fasade bangunan kemudian dianalisis lebih lanjut untuk menyimpulkan dan mengidentifikasi melalui gaya Arsitektur peninggalan Kolonial pada Masa Transisi/Peralihan dan karakter dari Fasade sebagai visual dari bangunan. 
Tabel 1. Variabel Penelitian

\begin{tabular}{clll}
\hline No & \multicolumn{1}{c}{ Konsep } & \multicolumn{1}{c}{ Indokator } & Metode Penelitian \\
\hline 1. & Gaya Bangunan & - Sejarah Bangunan dan Perkembangan & Survei Visual, \\
& & - Denah & Pengukuran dan \\
& & Dokumentasi \\
& & \\
& & - Material Bangunan & \\
& & - Sistem Konstruksi & \\
& & Atap & Survei Visual, \\
2. Karakter Fasad Bangunan & - Dinding Eksterior & Pengukuran dan \\
& & - Pintu & Dokumentasi \\
& & - Jendela & \\
\hline
\end{tabular}

\section{HASIL DAN PEMBAHASAN}

Kawsan Banda Sakti terletak di Jl. Merdeka Kota Lhokseumawe. Bangunan atau rumah yang diteliti yaitu Kantor Pos polisi di Jl. Merdeka, Rumah Dokter Hewan Belanda di Jl. Samudera Lancang Garam dan Rumah Bangsawan Belanda di Jl. Iskanda Muda. Bangunan tersebut merupakan bangunan peninggalan Arsitektur Transisi/Peralihan masa Kolonial Belanda pada masanya. Untuk mendapatkan Gaya Arsitektur Transisi/Peralihan Masa Kolonial Belanda dan Karakter fasade secara Visual pada sebuah bangunan atau objek penelitian yang diteliti antara lain berupa elemen: Gaya diantaranya Denah Bangunan, serta Tampak, Material dan Bahan Bangunan, Sistem Kontruksi. Pada karakter Fasade secara visual terdiri dari Atap, , Dinding Eksterior, Pintu, Jendela, dan Kolom.

\subsection{Pengertian dari Gaya pada Masa Arsitektur Transisi/Peralihan Kolonial Peninggalan Bangunan Belanda di Indonesia}

Secara etimologi di dalam bahasa Indonesia gaya menurut Kamus yang dibaca yaitu style, bearti yang merupakan alat pegores. Gaya atau Style merupakan suatu tanda-tanda yang mana seorang peneliti bisa memperkirakan atau dapat mengamati sebuah gaya melalui ciri-ciri kahasnya. Adanya gaya dipengaruhi karena kebutuhan, lingkungan serta seniman pelakunya. Menurut Bustami [2], lahirnya gaya karena diadopsi dari sebuah gaya yang sebelumnya, dan diaplikasikan menurut dengan kemampuan diri sampai melahirkan gaya baru.

Wardani dan Isada [3] mengatakan, Gaya Kolonial Belaanda(Dutch Colonialn Style) merupakan gaya desain yang populer di Belanda pada tahun 1624-1820. Gaya ini ini timbul karena adanya keinginan dan usaha bangsa Eropa untuk membuat daerah jajahan mirip seperti Daerah Tinggal Mereka di Eropa. Dan pada akhirnya, desain mereka yang tidak ada kesesuaian dengan wujud aslinya di karenakan perbedaan musim juga iklim, serta minimnya suplai bahan material dan juga perbedaan cara penguasaan teknik di negara jajahannya. Akhirnya didapatkan bentuk hasil dari modifikasi yang terlalu menyerupai hasil desain di negara Eropa.

Menurut Handinoto [4] gaya arsitektur Transisi/Peralihan pada masa Kolonial Belandadi Indonesia terbagi tiga yaitu: Gaya Arsitektur Masa Kerajaan Indische Dutch Empire Style (Abad 18-19), Aritektur Masa Transisi/Peralihan di tahun (1890-1915), dan Arsitektur Kolonial Modern (1915-1949), dapat dijabarkan sebagai keterangan berikut:

a. Gaya Arsitektur pada Masa Indische Empire Style (18-19)

Gaya ini diperkenalkan oleh Gubernur Jendral Kolonial Belanda Herman Willen Daendels saat bertugas tahun 1808-1811. Gaya Imperial/ Indische Empire Style merupakan suatu style langgam arsitektur mempengaruhi masa pertengahan abad ke-18 sampai abad ke-19. Gaya langgam arsitektur pada Masa Gaya Imperial /Indische Empire Style awalnya muncul pada daerah pinggiran kota Batavia (Jakarta), adanya gaya tersebut karena terpengaruh dari suatu kebudayaan Indische Dutch Culture yang berkembang di Belanda. Ciri-ciri asritektur Indische 
Empire Style yaitu: Dilihat dari denahnya terlihat simetris penuh, ada central room yang terdiri dari kamar tidur utama dan kamar tidur lainnya. Central room berorientasi langsung menuju dengan teras yang ada depan dan belakang. Teras tersebut biasanya ukuran lapang dan pengakhirannya terdapat sejumlah jajaran kolom yang berlanggan Yunani/Greek. Dapur, kamar mandi, bangunan penyimpanan dan bangunan service berorientasi terpisah dari bangunan rumah dan letaknya ada dibagian belakang.

b. Gaya pada Arsitektur Transisi/Peralihan Masa Kolonial Belanda (1890-1915)

Menurut Handinoto dan Hartono [5] gaya arsitektur transisi ini berlangsung sangat singkat di Indonesia akhir abad ke-19 sampai awal abad ke-20 antara tahun 1890-1915. Masa Transisi/Peralihan dari abad 19 ke abad 20 di Belanda dipenuhi dengan perubahan didalam masyarakat. Moderenisasi oleh inovasi terbaru dalam bagian teknologi dan transformasi sosial budaya akibat kebijakan politik kepemerintahan kolonial pada waktu itu berakibat berubahnya bentuk dan gaya didalam bangunan arsitektur. Transformasi Langgam Arsitektur pada masa transisi/peralihan (1890-1915) mulai dari Langgam Arsitektur Indische Dutch Empire menuju ke arsitektur Modern Colonial sering terlupakan. Ciri-ciri arsitektur transisi/peralihan menurut handinoto [5],Denah terlihat terpengaruh langgam Indische Ducth Empire Style, simetris penuh, pemakain teras sekitar rumah di denah digunakan dan ada usaha untuk meniadakan tiang/pilar langgam Yunani/Greek pada fasadnya. Kemudian Gable/gevel (terdapat pada bagian depan atau tampak bangunan, memiliki bentuk segitiga atau yang mengikuti bentuk dari atap itu sendiri) pada Arsitektur Kolonial penerapan perletakan muncul kembali, Kemudian berlanjut pada kegiatan perancangan yang menampilkan penampakan Romantis pada Fasade dan desain menara di main enterance serta Terlihat menyerupai atap pelana

dan perisai dengan jumlah genteng masih digunakan dan tetap untuk memakai kontruksi ventilasi pada atap (roof of top).

\section{c. Langgam Arsitektur Modern Colonial masa (1915-1940)}

Menurut H.Handinoto [6], arsitektur ini adalah kritik sejumlah arsitek-arsitek Kolonial Belanda sesudah tahun 1900 atas langgam Indische Dutch Empire Style. Arsitek Belanda yang yang mempunyai pendidikan akademis akhirnya mulai mempengaruhi gaya bangunan ke Hindia Belanda, mereka memperkirakan adanya langgam style arsitektur yang sangat asing, karena langgam arsitektur Empire Style yang berkembang di Eropa atau France tidak mendapat sambutan di Belanda. Ciri-ciri arsitektur Kolonial Moderen yaitu:

- Denah Bercorak dengan adaptasi menurut hasil kreatifitas dalam arsitektur Kolonial Moderen.

- Bentuk seimbang simetris banyak ditiadakan.

- Penggunaan teras memutari bangunan sudah tidak digunakan dan diterapkan penggunaan elemen sun shading sebagai pelindung sinar matahari.

- Mengurangi kesan fasade tampak arsitektur Indische Empire Style (tampak tidak simetris lagi),

- Fasade Tampak bangunan lebih mengikuti form follow function atau clean design.

- Bentuk atap masih sangat dipengaruhi oleh atap pelana atau perisai, dengan bahan penutup genteng sirap. Material bangunan dengan kontruksi beton, memakai atap datar dari bahan material beton yang belum digunakan pada zaman sebelumnya.

Kantor Pos Polisi ini adalah juga merupakan bahagian peninggalan Kolonial masa Belanda yang masih terlihat keberadaannya di pusat Kota Lhokseumawe. Sebelum menjadi kantor Pos Polisi bangunan ini dulunya merupakan Kantor PNKA dari tahun 1850-1951 dan sekarang baru berubah menjadi Pos polisi dari tahun 1951-sekarang. Fasade bangunan bergaya arsitektur Kolonialnya. Bangunan ini dibangun sekitar tahun 1850-an dan luas bangunan kurang lebih $84 \mathrm{~m}^{2}$. Bangunan ini sudah mengalami stasiun kereta api pertama yang menggunakan struktur dan langgam arsitektur Kolonial. Bentuk denah yang simetris. Ada terjadi perubahan pada bangunan ini yaitu pada bagian belakang, ruang belakangnya dijadikan teras. Bangunan ini terawat sehingga tingkat kerusakan nya kecil. beberapa perubahan Renovasi. Bangunan ini merupakan bangunan bangunan stasiun kereta api pertama yang menggunakan struktur dan 
langgam arsitektur Kolonial. Bentuk denah yang simetris. Ada terjadi perubahan pada bangunan ini yaitu pada bagian belakang, ruang belakangnya dijadikan teras. Bangunan ini terawat sehingga tingkat kerusakannya.

Tabel 2. Gaya Arsitektur Kolonial pada Kantor Sep Kereta Api (Pos Poisi)

Enalisis berdasarkan gaya arsitektur
peralihan/transisi


Rumah Dokter hewan belanda yang terletak di jalan Sultan Nahrisyah Lancang garam ini sudah ada sejak tahun 1850-an yang merupakan bangunan peninggalan belanda dan sudah beberapa kali direnovasi dari masa ke masa. Dan bangunan ini diganti rugi oleh Bapak (Alm) Muhammad Ali pada sekitar tahun 1963. Luas bangunan diperkirakan $80 \mathrm{M}^{2}$. Keseluruhan bangunan di dominasi bermaterial kayu.

Fungsi dari bangunan ini berubah seiring dengan pergantian kepemilikan rumah. Fungsi rumah dari masa ke masa tahun sebelum 60-an awalnya kepemilikan rumah ini merupakan Rumah Dinas Manteri Hewan Belanda, dan difungsikan sebagai rumah tinggalnya sekitar tahun 1960-1963. Dan sekarang dijadikan rumah tinggal. Bentuk belakang rumah ini sudah mengalami kerusakan. Hanya bagian depan yang terawat.

Bentuk denah yang simetris dengan banyak ruang, ruang-ruang mengelompok dan ruang berjajar memanjang. Orintasi bangunan utama menghadap halaman yang luas. Wujud atau bentuk pada arsitektur Kolonial ini terdpat dinding kayu, kolom kayu, pintu, jendela lebar dan tinggi. Bentuk atap limas an dan pelana ada elemen gable, menara dan dormer. Sisitem struktur arsitektur Kolonialnya yaitu dinding kayu dan pada kontruksi rangka atap dengan sistem rangka kuda-kuda. Bahan bangunan menggunkan kayu, besi, kaca, seng.

Tabel 3. Gaya Arsitektur Kolonial Rumah Dokter Hewan Bealnda

\begin{tabular}{|c|c|c|}
\hline \multicolumn{3}{|c|}{ Elemen Gaya Arsitektur (Handinoto 2010) } \\
\hline No. & Rumah Dokter Hewan Belanda & $\begin{array}{c}\text { Analisis berdasarkan gaya arsitektur } \\
\text { peralihan/transisi }\end{array}$ \\
\hline 1 & Denah & $\begin{array}{ll}\text { - } & \text { Denah simetris } \\
\text { - } & \text { Terdapat teras pada bangunan } \\
\text { - } & \text { Denah mengalami perubahan pada bagian } \\
\text { belakang. } \\
\text { - } \\
\text { Ruang bagian belakang dinding kamar mandi } \\
\text { sudah tidak ada. }\end{array}$ \\
\hline 2 & Tampak & $\begin{array}{l}\text { - } \quad \text { Tampak simetri } \\
\text { - } \quad \text { Terdapat beberapa tiang dari kayu yang terpisah } \\
\text { berbentuk persegi penyanggah atap teras. }\end{array}$ \\
\hline 3 & Bahan Bangunan & $\begin{array}{l}\text { - Menggunakan batu bata pada dinding bagian } \\
\text { dalam. Dan kayu bagian luar. } \\
\text { Menggunakan bahan material kayu baik } \\
\text { jendela, dindng, pintu maupun kuda-kuda. } \\
\text { Ventilasi material bahan kaca, tapi masih } \\
\text { sangat terbatas. }\end{array}$ \\
\hline 4 & Sistem Kontruksi & 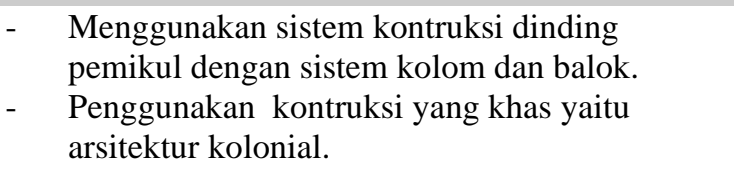 \\
\hline
\end{tabular}


Bangunan rumah Bangsawan Belanda yang terletak di jalan Iskandar Muda ini adalah peninggalan Kolonial Belanda dan sangat berbeda dengan bangunan-bangunan yang ada disekitarnya. Dari hasil wawancara dapat diketahui bahwa bangunan ini sudah mengalami perunahan yaitu pada pondasi. Dimana pondasi yang dulu terbuat dari material kayu yang dulu sudah tidak layak pakai, dan kemudia diganti dengan yang baru yang lebih kokoh. Rumah ini terdapat 4 kamar, ruang tamu, ruang keluarga, dapur dan kamar mandi.

Gaya bangunan rumah ini adalah langgam Arsitektur Kolonial masa Belanda yang mencampurkan beberapa budaya. Rumah dengan gaya Kolonial ini menjadi simbol untuk menentukan kelas atau status sosial seseorang. Arsitektur kolonial ini juga memiliki aspek pembeda yang lain yaitu memiliki cirri khas pada desain ruang ruangnya, bentu dan struktur maupun material. Ruang bangunan utama menghadap ke halaman yang luas. Atap mirip dengan atap pelana dan limas an. Bahan material utama yaitu kayu, batu seng dan besi.

Tabel 4. Gaya Arsitektur Kolonial Rumah Bangsawan Belanda

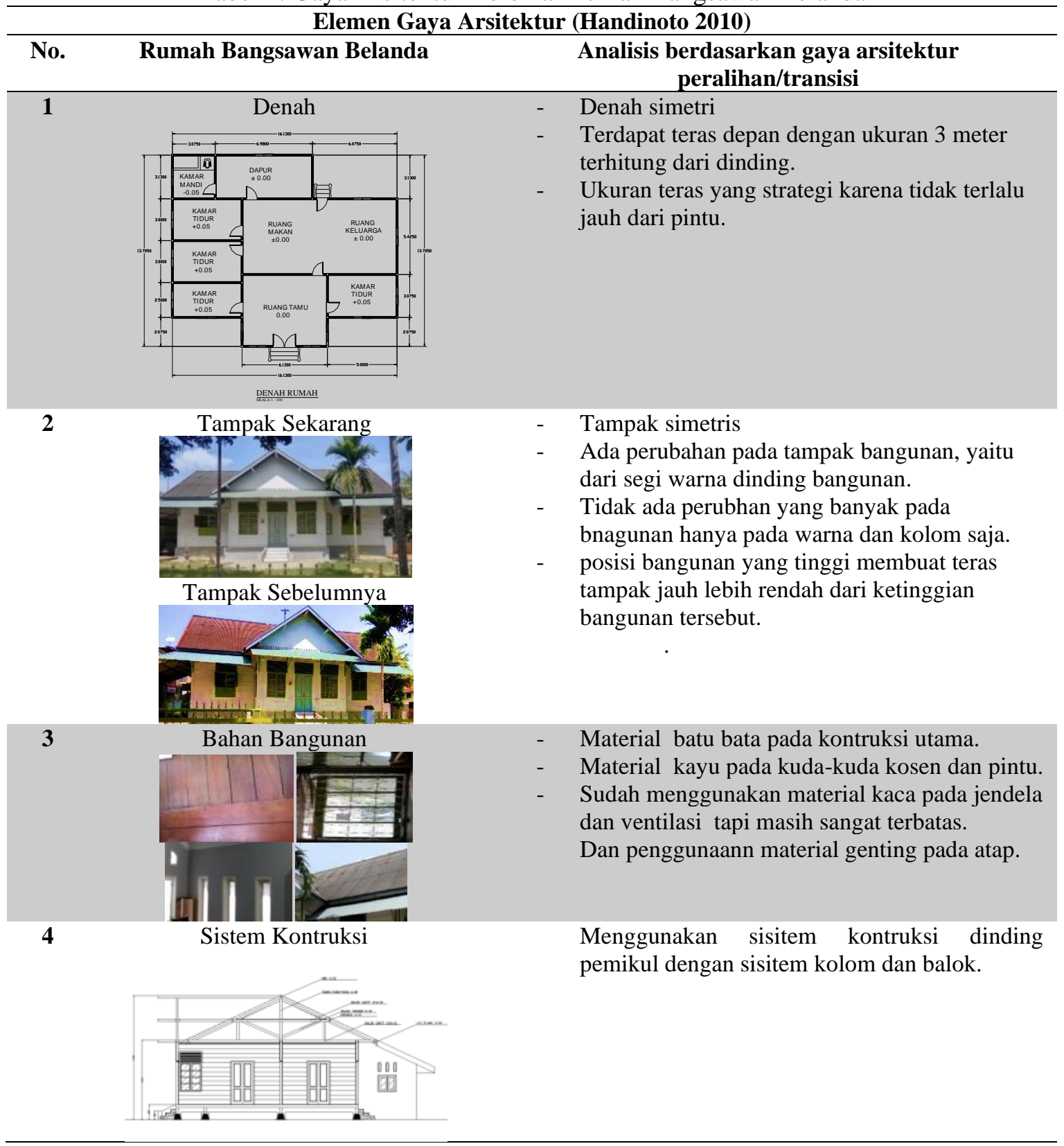




\subsection{Karakter Fasade Bangunan Kolonial masa Belanda di Indonesia}

Tampak fasade secara visual pada bangunan Kolonial masa Belanda di Indonesia mempunyai karakter visual yang berlanggam, ketidaksamaan karakter visual pada bangunan dapat dilihat berdasarkan langgam arsitektur pada bangunan tersebut. Karakter berdasarkan Adenan (2012) [6], adalah sebagai salah satu kelengkapan fitur yang membentuk dan memperjelas suatu individu. Karakter dapat dimengerti sebagai ciri khas yang didapat pada kelompok tertentu yang biasa digunakan untuk membedakan suatu individu atau kelompok tersebut dari individu atau kelompok lainnya. Untuk mendapatkan karakter fasade visual pada sebuah bangunan atau objek contoh yang digunakan antara lain elemen eksterior:

a. Karakter Visual Arsitektur Indische Ducth Empire Style Abad 18-19

Menurut Hartono dan Handinoto [7] adalah memiliki kontruksi atap perisai dengan penutup atap material genteng, bahan kontruksi utamanya seperti batu (baik pada tiang maupun dinding), pemakaian kayu terutama pada kuda-kuda, bingkai kusen maupun pintunya dan pemakaian material kaca belum banyak dipakai.

b. Karakter Visual Arsitektur Transisi/Peralihan (1890-1915)

Menurut Renashiru [8], karakter arsitektur transisi/peralihan mempunyai kontruksi atap pelana dan perisai, penutup material atap genting. Penggunaan ventilasi pada atap (dormer), bentuk atap tinggi dengan kemiringan besar antara $45^{\circ}-60^{\circ}$. Penggunaan bentuk lengkung, kolom bergaya Yunani/Greek sudah mulai dihilangkan, tiang sudah menggunakan material kayu dan beton, dinding pemikul. Bahan bangunan utama bata dan kayu serta penggunaan kaca (terutama pada jendela) masih sangat terbatas.

c. Karakter Visual Arsitektur Kolonial Modern (1915-1940)

Menurut [9] yaitu: memakai atap datar dari bahan beton, penggunaan gable/gevel horizontal, mulai memakai besi cor, mulai memakai material kaca dalam jumlah yang besar, dominan memakai warna putih. Dinding hanya berfungsi sebagai penutup dan pemakaian kaca (terutama pada jedela) yang cukup lebar. Menurut Wirawan [10] karakter dari sebuah bahagian arsitektur merupakan keberagaman atau kekhasan yang tersusun menjadi ciri-ciri suatu obyek arsitektural atau susunan elemen dasar yang terangkai sehingga membuat objek tersebut memiliki kualitas dan kekhasan yang membedakan dengan obyek lain.

Tabel 5. Karakter Fasade Visual Arsitektur Kolonial Kantor Sep Kereta Api (Pos Polisi)

\begin{tabular}{|c|c|c|}
\hline \multicolumn{3}{|c|}{ Karakter Visual (Handinoto 2006) } \\
\hline No. & Kantor Pos Polisi & $\begin{array}{c}\text { Analisis berdasarkan gaya arsitektur } \\
\text { peralihan/transisi }\end{array}$ \\
\hline 1 & Atap & $\begin{array}{ll}\text { - } & \text { Menggunakan model atap perisai } \\
\text { - } & \text { Dan material atap genteng. } \\
\text { - } & \text { struktur kayu pada kuda-kuda. } \\
\text { - } & \text { Terdapat hiasan yang meruncing ke atas pada } \\
\text { atap bagian depan dan belakang atap. }\end{array}$ \\
\hline 2 & Dinding Eksterior & $\begin{array}{l}\text { - Dinding bagian luar menggunakan material dari } \\
\text { kayu, bagian dalam menggunakan material dari } \\
\text { beton.kontruksi dinding pemikul. } \\
\text { - Terdapat hiasan atau ornamen pada dinding } \\
\text { bagian luar berbentul symbol plus(tambah) } \\
\text { namun sisi atas dan bawahnya sedikit lebih } \\
\text { panjang dibnadingkan bagian sisi kanan dan } \\
\text { kirinya. } \\
\text { Di ke empat sisi bangunan memiliki ornamen } \\
\text { tersebut.. }\end{array}$ \\
\hline
\end{tabular}




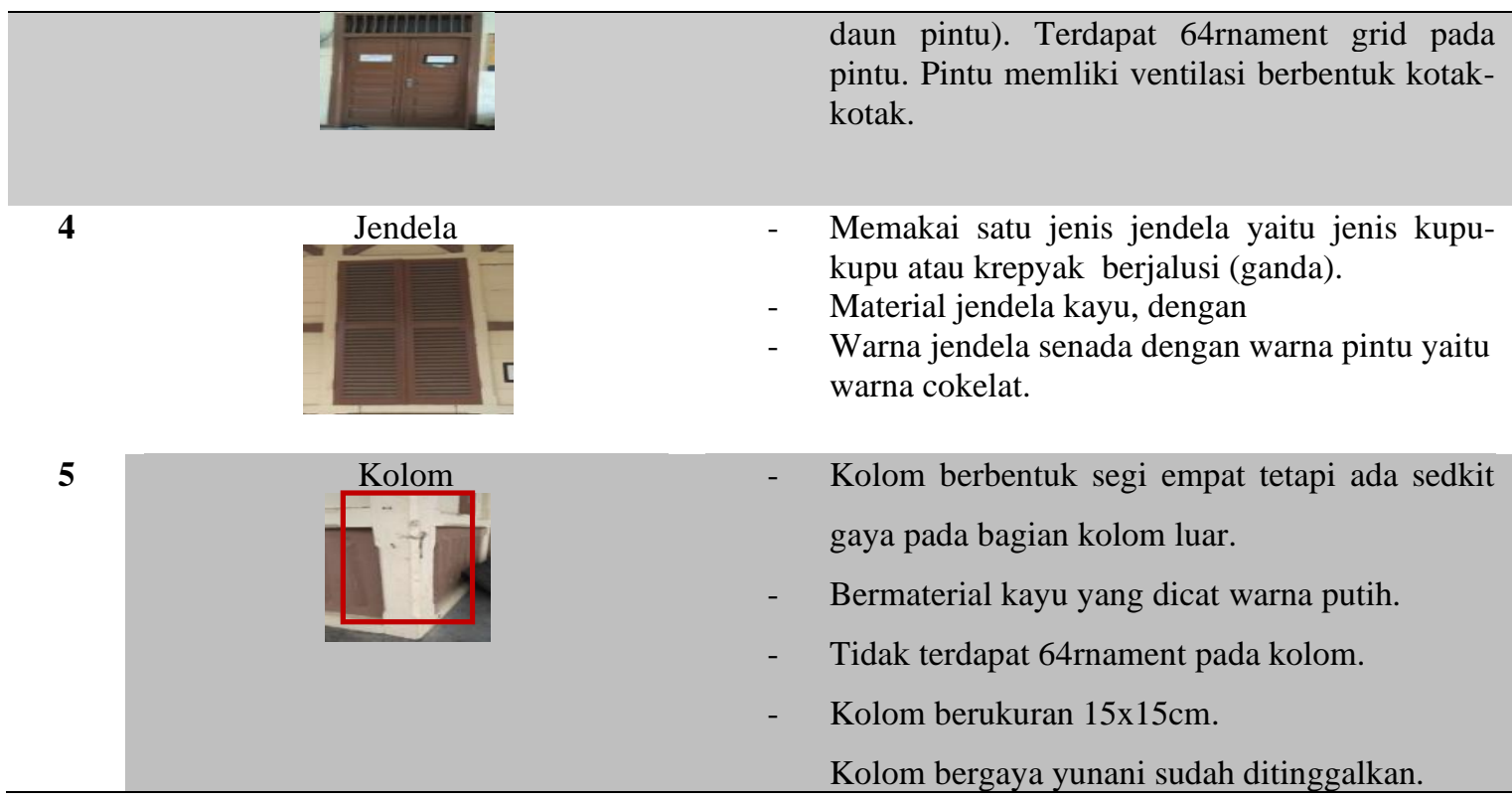

Tabel 6. Karakter Fasade pada Visual Arsitektur Kolonial Rumah Dokter Hewan Belanda

\begin{tabular}{|c|c|c|}
\hline \multicolumn{3}{|c|}{ Karakter Visual (Handinoto 2006) } \\
\hline No. & Rumah Dokter Hewan Belanda & $\begin{array}{c}\text { Analisis berdasarkan gaya arsitektur } \\
\text { peralihan/transisi }\end{array}$ \\
\hline 1 & Atap & $\begin{array}{ll}\text { - } & \text { Kontruksi atap kuda-kuda dan jenis atap } \\
\text { genteng. } & \\
\text { - } & \text { Atap berbentuk limasan dan pelana } \\
\text { - } & \text { Terdapat elemen menara pada atap. } \\
\text { - } & \text { Mempunyai kemiringan atap 45'. } \\
\text { - } & \text { Dengan ventilasi cirri khas kolonial. } \\
\text { - } & \text { Ada elemen menara atau hiasan pada bagian } \\
\text { atap. }\end{array}$ \\
\hline 2 & & $\begin{array}{l}\text { - Bahan dasar material kayu Merbo baik struktur } \\
\text { maupun dinding. } \\
\text { - Tidak terdapat 64rnament yang mencolok pada } \\
\text { dinding. } \\
\text { - Dinding dengan warna dasar kayu/tidak di cat. } \\
\text { - Ada kerusakan pada dinding bagian kanan utara } \\
\text { dan belakang sehingga digantikan bahan } \\
\text { material seng. }\end{array}$ \\
\hline 3 & Pintu & $\begin{array}{l}\text { - Pintu terbuat dari material kayu. Terdapat dua } \\
\text { jenis pintu di bagian eksteriornya. Jenis satu, } \\
\text { pintu ganda (dua daun pintu ) dengan } \\
\text { 64rnament geometri persegi denagn ventilasi } \\
\text { berjenis jalusi. Jenis pintu dua satu daun pintu } \\
\text { dengan ventilasi yang tertutup berornamen } \\
\text { geometri persegi. } \\
\text { - Pintu sangat terlihat dari bnetuk dan ukurannya }\end{array}$ \\
\hline
\end{tabular}




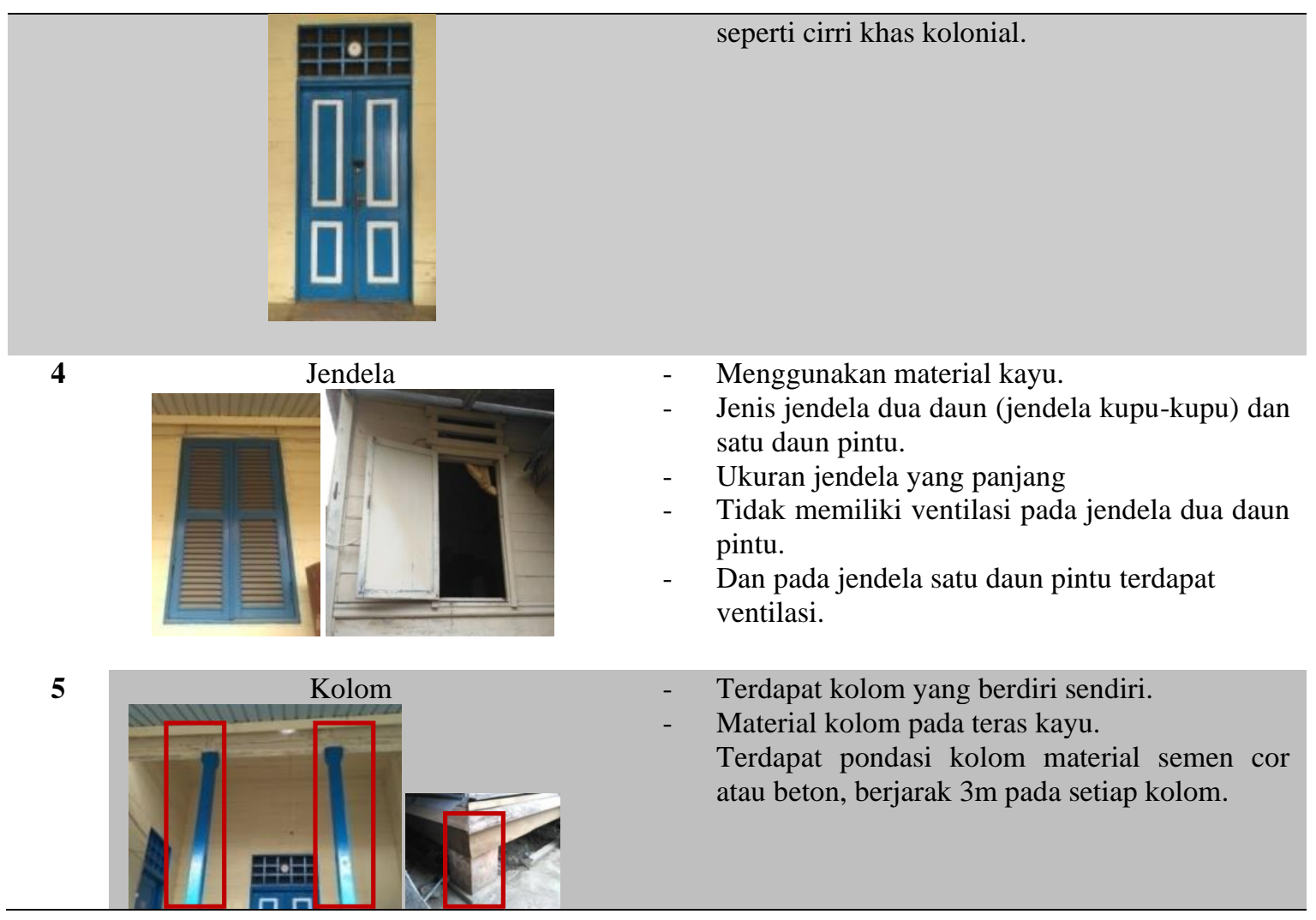

Tabel 7. Karakter Fasade pada Visual Arsitektur Kolonial Bangsawan Belanda

\begin{tabular}{|c|c|c|}
\hline \multicolumn{3}{|c|}{ Karakter Visual (Handinoto 2006) } \\
\hline No. & Rumah Bangsawan Belanda & $\begin{array}{c}\text { Analisis berdasarkan gaya arsitektur } \\
\text { peralihan/transisi }\end{array}$ \\
\hline 1 & Atap & $\begin{array}{ll}\text { - } & \text { Atap perisai. } \\
\text { - } & \text { Material atap genteng. } \\
\text { - } & \text { Struktur atap kuda-kuda material kayu. }\end{array}$ \\
\hline 2 & Dinding Eksterior & $\begin{array}{l}\text { - } \quad \text { Material dinding kayu. } \\
\text { - } \quad \text { Terdapat motif grid pada dinding bagian depan } \\
\text { pintu masuk. } \\
\text { - } \quad \text { Sekarang warna dinding di cat dengan warna putih. } \\
\text { - } \quad \text { Sebelumnya dinding berwarna pink. } \\
\text { - } \quad \text { Tidak ada perubahan yang banyak pada bagian } \\
\text { dinding. }\end{array}$ \\
\hline 3 & Pintu & $\begin{array}{l}\text { - } \quad \text { Pintu masuk dari bahan material kayu. } \\
\text { - } \quad \text { Memiliki } 65 \text { rnament motif grid. } \\
\text { - } \quad \text { ventilasi berjalusi pada pintu masuk. Pintu } \\
\text { terdiri dari warna biru muda dan hijau tua. } \\
\text { - Pintu sangat berciri khas kolonial. }\end{array}$ \\
\hline 4 & Jendela & - Material jendela kayu tetapi sudah mulai \\
\hline
\end{tabular}




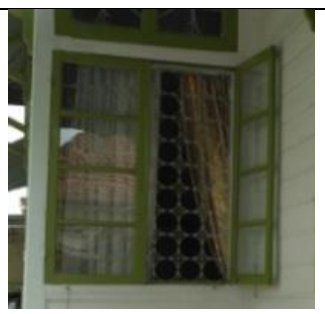

menggunakan kaca yang masih terbatas.

- Jendela terletak di bagian depan saping kiri, kanan dan belakang bangunan.

- $\quad$ Tipe jendela ganda (krepyak) dan jendela mati.

- $\quad$ ada jalusi dari besi di bagian dalam jendela, tapi tidak kesemua jendela hanya bebrapa saja.

5

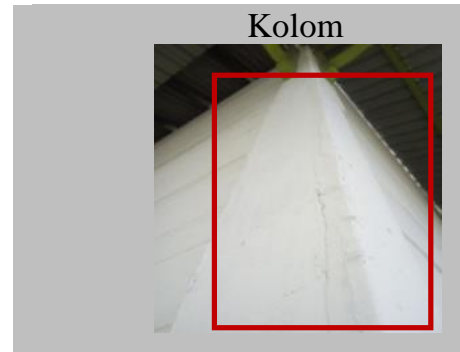

Bahan material kolom kayu jati, sehingga bisa bertahan lebih dari 50 tahun.

Ada sedikit keretakkan pad akolom ini

Terdapat kolom yang menyatatu dengan dinding. Kolom diameter $15 \times 15 \mathrm{~cm}$.

- Kolom berbentuk segi empat dengan warna kolom senada dengan dinding warna putih.

- Kolom dicat agar tiang kolom semakin kuat dan tahan lama.

Tidak terdapat ornamen pada kolom.

\section{KESIMPULAN}

Berdasarkan analisa identifikasi dan hasil pemaparan sebelumnya dapat diberi kesimpulan sebagai berikut:

1. Terdapat banyak sekali Gaya dan Langgam Karakter visualnya arsitektur Kolonial yang pernah hadir di Indonesia, sampai dipalikasikan pada bangunan-bangunan yang disebutkan dengan bangunan kolonial. Antara lain: gaya arsitektur pada Masa Kerajaaan Indische Ducth Empire Style, Gaya Arsitektur Peralihan/Transisi, Gaya Arsitektur Moderen, Gaya International Style, Gaya Nieuwe, Gaya Ekspresionitik, Gaya Art Deco.

2. Dan Gaya serta karakter visual ketiga bangunan tersebut di atas yang berada di Kota Lhokseumawe Kecamatan Banda Sakti sebagian lebih mendekati gaya arsitektur transisi/peralihan. Dilihat dari tahun berdirinya yaitu pada sekitar tahun 1890-1915, gaya bangunannya meliputi (Denah Layout Bangunan, tampak, bahan bangunan, sistem Material kontruksi) dan pada karakter visualnya antara lain: (atap, dinding ekterior, pintu, jendela dan kolom) merupakan ciri dari gaya arsitektur peralihan/transisi dengan konsep perancangan bangunan nya gabungan dari desain arsitektur Belanda dengan penyesuaian iklim tropis di Indonesia.

3. Keberadaan bangunan bersejarah seperti kolonial merupakan bukti yang sangat penting tentang perkembangan dari suatu tempat. Tentang sejarah sebuah kota, perkembangan arsitekturnya, tentang kebudayaannya dan tentang pemeritahannya. Bangunan Pos Polisi, Rumah Dokter Hewan Belanda dan Rumah Bangsawan Belanda adalah beberapa bangunan Peninggalan kolonial yang ada di Kecamatan Banda Sakti Kota Lhokseumawe.

4. Peninggaalan sejarah di Kecamatan Banda Sakti ini merupakan warisan budaya yang harus dipertahankan keberadaannya, baik bentuk fisik bangunan dan historisgrafi sejarahnya.

5. Jika dilihat kondisi dari ketiga bangunan diatas dulunya memang terabaikan tanpa ada campur tangan yang mau merawat, namun seiring waktu bangunan. Itu sudah mulai terawat kondisinya dilihat dari keadaan bangunannya sekarang sudah sangat membaik dan terawat.

6. Karakter Fasade Secara Visual pada ketiga bangunan peninggalan Kolonial Belanda tersebut yang ada di Kecamatan Banda Sakti antara lain: memiliki atap perisai dan pelana dengan penutup atap genteng. Dinding merupakan kontruksi dinding pemikul. Bahan material dinding beton dan kayu. Kolom terbuat dari kayu yang berbentuk persegi. Model, jenis, ukuran, jumlah dan perletakkan setiap bangunan berbeda. Pintu berjenis pintu ganda atau dua daun pintu dan pintu berjenis satu daun pintu menggunakan bahan materal kayu. Model, jenis, ukuran, jumlah dan perletakkan berbeda. Jendela terdapat tiga model atau jenis yaitu, jendela panel kayu masif, jendela krepyak atau dua daun pintu dan jendela pelapis kaca. Jendela menggunakan bahan kayu dan kombinasi kaca polos/bening. 
Dari hasil penelitian ini yaitu “ Identifikasi Langgam Gaya Arsitektur Transisi/Peralihan dan Karakter Visual fasade Arsitektur Peninggalan Kolonial di Kecamatan Banda Sakti Kota Lhokseumawe" ini dapat diharapkan bisa menjadi acuan atau referensi mengenai Bangunan Bersejarah Kolonial di Kota Lhokseumawe maupun yang ada dikota lainnya. Dengan adanya penelitian ini bisa membuka wawasan kita mengenai pentingnya mengetahui atau pengetahuan tentang bangunan bersejarah yang ada disekitar kita agar tidak sia-sia keberadaannya.

Serta peneliti mengharapkan supaya bangunan bersejarah yang ada di Kota Lhokseumawe ini, kita semua bisa mengambil pelajaran dari bangunan tersebut sebagai bahan sejarah dan pembelajaran. Selanjutnya, menjadikan bangunan kolonial bersejarah mempunyai nilai historis yang berharga keberadaannya dengan cara menjelaskan kemabali sejarah peninggalannya, memahami fungsi dan keguanaanya, dan mengaplikasikannya secara pendidikan, parawisata dan juga ekonomi kedalam kehidupan.

\section{DAFTAR PUSTAKA}

[1] N. Muhadjir, Metodologi Penelitian Kualitatif, 4th ed. Yogyakarta: Rake Sarasin, 2000.

[2] S. . Bustami, Studi Komparasi Gaya Seni Yogya-Solo. Yogyakarta: Yayasan Untuk Indonesia, 2000.

[3] L. K. Wardani and A. Isada, "Gaya Desain Kolonial Belanda pada Interior Gereja Katolik Hati Kudus Yesus Surabaya,” Dimens. Inter., vol. 7, no. 1, 2009, doi: 10.9744/interior.7.1.pp. 52-64.

[4] Handinoto, Arsitektur dan Kota-kota di Jawa Pada Masa Kolonial. Yogyakarta: Graha Ilmu, 2010.

[5] H. Handinoto and S. Hartono, “ARSITEKTUR TRANSISI” DI NUSANTARA DARI AKHIR ABAD 19 KE AWAL ABAD 20 (Studi Kasus Komplek Bangunan Militer di Jawa pada Peralihan Abad 19 ke 20)," Dimens. J. Archit. Built Environ., vol. 34, Jan. 2006.

[6] Handinoto, "Arsitek G.C. Citroen dan perkembangan arsitektur kolonial Belanda di Surabaya (1915-1940)," Dimensi, vol. 19, 1993.

[7] S. Hartono and Handinoto, “Arsitektur Transisi' di nusantara dari akhir abad 19 ke awal abad 20 (studi kasus komplek bangunan militer di Jawa pada peralihan abad 19 ke 20)," Dimens. Tek. Arsit., vol. 34, no. 2, pp. 81-92, 2006.

[8] Renashiru, "Arsitektur Kolonial Belanda," 2018. [Online]. Available: http://www.slideshare.net/renashtiru/arsitektur-kolonial.

[9] "Sejarah Lhokseumawe." [Online]. Available: https://bappeda.lhokseumawekota.go.id/.

[10] G. Wirawan, "Arsitektur Kolonial," 2015. [Online]. Available: https://dheavours.wordpress.com/2015/06/11/arsitektur-kolonial/amp/. 